\title{
PENGARUH MODAL KERJA TERHADAP PROFITABILITAS PERUSAHAAN PADA BUKIT ASAM TBK
}

\author{
Tia Nurhayati Nasifah ${ }^{1}$, Sukomo $^{2}$, Endang Mulyadi ${ }^{3}$ \\ 1,2,3 Program Studi Pendidikan Akuntansi, Universitas Galuh, Jl. R. E. Martadinata No.150, Ciamis, Indonesia \\ Email:nasifahtianurhayati@gmail.com
}

\begin{abstract}
An analysis of working capital is very important for internal and external analysts, this working capital problem is closely related to the daily operations of the company and also shows the level of security of creditors, especially short-term creditors. The purpose of this study was to determine (1) the magnitude of the development of working capital at PT Bukit Asam Tbk, (2) the magnitude of the profitability development achieved at PT Bukit Asam Tbk, (3) the magnitude of the effect of working capital on profitability at PT Bukit Asam Tbk. The research method used in this study is a quantitative method. The type of data is time series, data collection techniques are carried out through library research and documentation. The results showed that (1) The amount of working capital as measured by the working capital ratio at PT Bukit Asam Tbk from year to year fluctuated with an average of $23.57 \%$ every year, and when viewed from its development it increased by $2.58 \%$ every year. year. (2) The level of profitability at PT Bukit Asam Tbk from year to year fluctuates with an average of $19.04 \%$ annually and when viewed from its development has increased by $0.96 \%$ annually. (3) Working capital as measured by the working capital ratio has a positive and significant effect on the company's profitability at PT Bukit Asam Tbk, while the magnitude of the effect is $79.21 \%$.
\end{abstract}

Keywords: Working Capital, Profitability

\section{ABSTRAK}

Suatu analisis terhadap modal kerja sangat penting bagi penganalisa intern maupun ekstern, masalah modal kerja ini erat hubungannya dengan operasi perusahaan sehari-hari juga menunjukan tingkat keamanan para kreditur terutama kreditur jangka pendek. Adapun tujuan dari penelitian ini adalah untuk mengetahui (1) Besarnya perkembangan modal kerja pada PT Bukit Asam Tbk, (2) Besarnya perkembangan profitabilitas yang dicapai pada PT Bukit Asam Tbk, (3) Besarnya pengaruh modal kerja terhadap profitabilitas pada PT Bukit Asam Tbk. Metode penelitian yang digunakan dalam penelitian ini adalah metode kuantitatif. Jenis datanya adalah runtut waktu, teknik pengumpulan data dilakukan melalui studi kepustakaan dan dokumentasi.Hasil penelitian menunjukan bahwa (1) Besarnya modal kerja yang diukur dengan rasio modal kerja pada PT Bukit Asam Tbk dari tahun ketahun mengalami fluktuatif dengan rata-rata setiap tahunnya sebesar $23,57 \%$, dan jika dilihat dari perkembangannya mengalami kenaikan sebesar $2,58 \%$ setiap tahunnya(2) Besarnya tingkat profitabilitas pada PT Bukit Asam Tbk dari tahun ketahun mengalmi fluktuatif dengan ratarata setiap tahunnya sebesar $19,04 \%$ dan jika dilihat dari perkembangannya mengalami kenaikan sebesar $0,96 \%$ setiap tahunnya. (3) Modal kerja yang diukur dengan rasio modal kerja mempunyai pengaruh positif dan signifikan terhadap profitabilitas perusahaan pada PT Bukit Asam Tbk, adapun besarnya pengaruh sebesar 79,21\%.

Kata kunci: Modal Kerja, Profitabilitas

Cara sitasi: Nasifah, T. N., Sukomo., \& Mulyadi, E. (2021). Pengaruh Modal Kerja Terhadap Profitabilitas Perusahaan Pada PT. Bukit Asam, Tbk.. J-KIP (Jurnal Keguruan dan IImu Pendidikan), 2 (3), 87-94. 


\section{PENDAHULUAN}

Perkembangan ekonomi yang mendorong kearah kompetisi yang cukup ketat, maka tantangan atau tuntutan yang harus dihadapi oleh sektor dunia usaha saat ini semakin berat pula. Perusahaan dalam menjaga kelangsungan usaha, harus meningkatkan profitabilitas karena profitabilitas sangat diperlukan untuk menilai perubahan potensi sumber daya ekonomi yang mungkin dikendalikan di masa depan. Selain itu, berguna dalam mengukur efektifitas perusahaan dalam memanfaatkan sumber daya. Profitabilitas menurut Munawir (2019) adalah "kemampuan perusahaan untuk mengukur profit yang diperoleh dari modal modal yang digunakan untuk operasi tersebut atau kemampuan perusahaan untuk memperoleh keuntungan". Profitabilitas dapat diartikan sebagai kemampuan perusahaan menghasilkan laba (profit).

Informasi tingkat profitabilitas suatu perusahaan dapat dijadikan dasar untuk mengukur keberhasilan perusahaan dalam memperoleh laba selama periode tertentu, memotivasi perusahaan untuk tetap beroperasi, menarik minat para investor untuk menanamkan modal. Sebagai dasar penelitian, penulis mengajukan data awal sebagai berikut :

Tabel 1. Profitabilitas PT Bukit Asam Tbk (Dalam juta rupiah)

\begin{tabular}{cccc}
\hline Tahun & Laba Bersih & Penjualan & Profitabilitas \\
\hline 2015 & 2.037 .111 & 13.845 .199 & $14,71 \%$ \\
2016 & 2.024 .405 & 14.058 .869 & $14,40 \%$ \\
2017 & 4.547 .232 & 19.471 .030 & $23,35 \%$ \\
2018 & 5.121 .112 & 21.166 .993 & $24,19 \%$ \\
2019 & 4.040 .394 & 21.785 .564 & $18,54 \%$ \\
\hline
\end{tabular}

Sumber: PT Bukit Asam Tbk

Tabel 1 menggambarkan bahwa pada tahun 2015 tingkat profitabilitas PT Bukit Asam Tbk sebesar 14,71\%, pada tahun 2016 mengalami penurunan sebesar 0,31\%, pada tahun 2017 mengalami kenaikan sebesar 8,95\%, pada tahun 2018 mengalami kenaikan sebesar 0,84\%, pada tahun 2019 penurunan sebesar 5,65\%. Dapat dikatakan bahwa profitabilitas PT Bukit Asam Tbk tingkat profitabilitas perusahaan bersifat fluktuatif.

Masalah yang dihadapi PT Bukit Asam yaitu tingkat profitabilitas perusahaan bersifat fluktuatif. Dari tahun 2015 hingga 2019 mengalami kenaikan dan penurunan yang cukup signifikan. Profitabilitas perusahaan yang bersifat fluktuatif ini disebabkan oleh kurangnya pengendalian pengeluaran kas untuk kegiatan operasi perusahaan yaitu dalam menekan beban - beban seperti beban pokok penjualan dan beban usaha. Kenaikan beban pokok penjualan dan beban usaha akan menekan laju peningkatan laba tahun berjalan. Semakin tinggi kenaikan beban pokok penjualan dan beban usaha maka laba tahun berjalan akan menurun.

Salah satu faktor yang dapat meningkatkan profitabilitas yaitu modal kerja yang memungkinkan bagi perusahan untuk tetap beroperasi, meminimalisir kesulitan, atau bahaya bahaya yang mungkin timbul karena adanya krisis atau kekacauan keuangan, selain itu dengan adanya modal kerja yang cukup perusahaan dapat melakukan proses produksi, sehingga tujuan perusahaan dapat dicapai. Akan tetapi adanya modal kerja yang berlebihan menunjukkan adanya dana yang tidakproduktif, dan hal ini akan berpotensitimbulnya kerugian bagi perusahaan. Sebaliknya adanya mis-managemen dalam modal kerja merupakan sebab utama kegagalan suatu perusahaan.

Menurut Subardi (dalam Yani \& Martha, 2016) keputusan yang mendasari manajemen modal kerja yang sehat ada dua yaitu:

1. Tingkat investasi optimal dalam aktiva lancar.

2. Campuran pembelanjaan jangka pendek dan pembelanjaan jangka panjang yang digunakan untuk mendukung investasi dalam aktiva lancar. 
Keputusan-keputusan tersebut dipengaruhi oleh hasil yang diharapkan dari profitabilitas. Mengurangi tingkat investasi aktiva lancar, asalkan masih mampu memenuhi penjualan, akan mengarah pada peningkatan "Earning PerShare" perusahaan. Untuk investasi dimana biaya eksplisit pembelanjaan jangka pendek lebih kecil dari pada harga pembelanjaan jangka panjang, semakin besar porsi utang lancar maka semakin besar profitabilitas perusahaan Subardi (Yani \& Martha, 2016).

Keterangan di atas dapat disimpulkan bahwa hubungan antara modal kerja dan profitabilitas adalah komposisi modal kerja yang tepat akan pengaruh kepada tingkat profitabilitas. Anwar (2018) berpendapat bahwa "Modal kerja adalah dana yang dialokasikan untuk keperluan pembiayaan operasional perusahaan yang jangka waktu pengeluaran dana tersebut maksimal satu tahun".

Tabel 2. Modal Kerja PT Bukit Asam Tbk Tahun 2015-2019

\begin{tabular}{crr}
\hline Tahun & Modal Kerja & Perkembangan Dalam \% \\
\hline 2015 & 9.287 .547 & $13,61 \%$ \\
2016 & 10.552 .405 & $30,80 \%$ \\
2017 & 13.799 .985 & $17,90 \%$ \\
2018 & 16.269 .696 & $13,23 \%$ \\
2019 & 18.422 .826 & $18,90 \%$ \\
\hline \multicolumn{2}{c}{ Rata-Rata Kenaikan }
\end{tabular}

Tabel 2 menggambarkan bahwa pada tahun 2015 modal kerja sebesar Rp.9.287.547.000.000,00, pada tahun 2016 mengalami kenaikan sebesar13,61\%, pada tahun 2017 mengalami kenaikan sebesar $30,80 \%$, pada tahun 2018 mengalami kenaikan sebesar $17,90 \%$, pada tahun 2019 mengalami kenaikan sebsar 13,23\%. Maka dapat dikatakan bahwa modal kerja PT Bukit Asam Tbk sejak tahun 2015 - 2019 mengalami kenaikan setiap tahunnya.

PT Bukit Asam setiap tahunnya mengalami kenaikan modal kerja yang dihasilkan dari penambahan laba bersih perusahaan, hanya saja masalah yang terjadi di PT Bukit Asam Tbk adalah peningkatan modal kerja setiap tahunnya fluktuatif. Rata-rata kenaikan modal kerja adalah sebesar 18,90\%. Kenaikan tingkat modal kerja paling rendah terjadi di tahun 2019 sebesar 13,23\%, pada tahun 2016 sebesar 13,61\%, dan pada tahun 2018 sebesar 17,90\%, jumlah ketiganyalebih kecil dari rata- rata peningkatan modal kerja selama 5 (lima) tahun terakhir dari periode 2015 - 2019. Besar peningkatan modal kerja tersebut dipengaruhi oleh naik turunnya laba bersih perusahaan.

Menurut Riyanto (2010) besar kecilnya kebutuhan modal kerja tergantung kepada (dua) faktor yaitu :

1. Periode perputaran atau terikatnya modal kerja adalah keseluruhan atau jumlah-jumlah dari periode-periode yang meliputi jangka waktu pemberian kredit beli, lama penyimpanan bahan mentah di gudang, lamanya proses produksi, lamanya barang jadi disimpan diguadang, dan jangka waktu penerimaan piutang.

2. Pengeluaran kas rata-rata setiap harinya adalah jumlah pengeluaran kas rata-rata setiapa harinya untuk keperluan pembelian bahan mentah, bahan pembantu, pembayaran upah buruh, dan biaya-biaya lainnya.

Keuntugan modal kerja menurut Munawir (2019) adalah sebagai berikut :

1. Melindungi perusahaan terhadap krisis modal kerja karena turunnya nilai dari aktiva lancar.

2. Memungkinkan untuk dapat membayar semua kewajiban-kewajiban tepat pada waktunya.

3. Menjamin dimilikinya kredit standing perusahaan semakin besar dan memungkinkan bagi perusahaan untuk dapat menghadapi bahaya-bahaya atau kesulitan keuangan yang mungkin terjadi. 
4. Memungkinkan untuk memiliki Persediaan dalam jumlah yang cukup untuk melayani para konsumennya.

5. Memungkinkan bagi perusahaan untuk memberikan syarat kredit yang lebih menguntungkan kepada para langganannya.

6. Memungkinkan bagi perusahaan untuk dapat beroperasi dengan lebih efisien karena tidak ada kesulitan untuk memperoleh barang ataupun jasa yang dibutuhkan.

Hanafi (2018) mendefinisikan Rasio Profitabilitas sebagai berikut : "Rasio Profitabilitas untuk mengukur kemampuan peusahaan menghasilkan keuntungan (profitabilitas) pada tingkat penjualan, aset dan modal saham tertentu". Menurut Hanafi (2018) ada tiga rasio yang sering dibicarakan yaitu profit margin, return on total asset (ROA), dan return on equity (ROE). Profit margin menghitung sejauh mana kemampuan perusahaan menghasilkan laba bersih pada tingkat penjualan tertentu. Rasio ini bisa di lihat secara langsung pada analisis common size untuk laporan laba rugi. Rasio ini juga di interpretasikan sebagai kemampuan perusahaan menekan biaya-biaya (ukuran efisiensi) di perusahaan pada periode tertentu.

Ada beberapa penelitian yang telah dilakukan mengenai Pengaruh Modal Kerja Terhadap Profitabilitas Perusahaan, diantaranya dilakukan oleh Reimeinda, Murni \& Saerang (2016), hasil penelitiannya adalah Perputaran modal kerja bersih (Working Capital Turnover) tidak mempengaruhi Profitabilitas pada perusahaan telekomunikasi di Indonesia baik secara parsial maupun simultan. Penelitian berikutnya dilakukan oleh Khorrunisa, Sasongko \& Endah (2017), yang menyimpulkan bahwa Secara simultan atau bersama-sama variabel modal kerja, cash turnover, receivable turnover dan inventory turnover berpengaruh tidak signifikan terhadap profitabilitas Pada PT. Mayora Indah Tbk. Penelitian berikutnya dilakukan oleh Tnius (2018), hasil penelitiannya adalah modal kerja berpengaruh signifikan terhadap profitabilitas pada PT Hanjaya Mandala Sampoerna Tbk. Selain itu ada juga penelitian yang dilakukan oleh Marda (2019), yang menyimpulkan bahwa modal kerja berpengaruh positif dan signifikan terhadap profitabilitas PT Astra International Tbk di Bursa Efek Indonesia.

Berdasarkan uraian latar belakang diatas modal kerja dan profitabilitas perusahaan menjadi perhatian penulis untuk diteliti lebih mendalam, dengan berjudul "Pengaruh Modal Kerja Terhadap Profitabilitas Perusahaan Pada PT Bukit Asam Tbk." Tujuan dari penelitian ini yaitu: 1) Untuk mengetahui besarnya perkembangan modal kerja yang diukur dengan rasio modal kerja pada PT Bukit Asam Tbk.; 2) Untuk mengetahuibesarnya perkembangan profitabilitas yang dicapai pada PT Bukit Asam Tbk.; 3) Untuk mengetahui besarnya pengaruh modal kerja yang diukur dengan rasio modal kerja terhadap profitabilitas pada PT Bukit Asam Tbk.

\section{METODE PENELITIAN}

Menurut Hadari Nawawi (2007) dalam Wahyu (2021) metode deskriptif adalah prosedur pemecahan masalah yang diselidiki dengan menggambarkan/ melukiskan keadaan subyek/obyek penelitian (seseorang, lembaga, masyarakat dan lain-lain) pada saat sekarang berdasarkan faktafakta yang tampak sebagaimana adanya. Metode penelitian yang digunakan dalam penelitian ini adalah metode kuantitatif karena hanya dinyatakan dengan angka dan dianalisis dengan menggunakan pendekatan analisis statistik. Dengan cara mengumpulkan berbagai data yang dibutuhkan kemudian dianalisis dengan menggunakan perhitungan rasio profitabilitas melalui laporan keuangan pada tahun 2015-2019 pada perusahaan PT. Bukit Asam Tbk yang terdaftar di Bursa Efek Indonesia.Jenis data penelitian yang digunakan adalah data Time Series (Runtut Waktu), yaitu data yang dikumpulkan pada suatu objek sepanjang periode waktu tertentu. Penelitian ini dapat dilihat dari data neraca dan laba rugi pada PT Bukit Asam Tbk dari periode 2015-2019.

Variabel dalam penelitian ini terdiri dari dua variabel, yaitumodal kerja sebagai variabel independen danprofitabilitas variabel dependen. Dalam penelitian ini, data yang digunakan sebagai bahan 
analisis adalah data sekunder yang bersumber dari data perusahaan berupa laporan keuangan PT. Bukit Asam Tbk yang terdaftar di Bursa Efek Indonesia di www.idx.co.id melalui Galeri Investasi Fakultas Ekonomi Unigal Ciamis.

Teknik pengumpulan data merupakan prosedur yang sistematis dan standar untuk memperoleh data yang diperlukan dan yang dikumpulkan harus cukup valid untuk digunakan. Teknik pengumpulan data yang digunakan yaitu studi kepustakaan dan dokumentasi yaitu berupa laporan keuangan PT. Bukit Asam Tbk yang terdaftar di Bursa Efek Indonesia melalui Galeri Investasi Fakultas Ekonomi Unigal Ciamis.

Teknik analisis data kuantitatif merupakan metode analisis dengan menggunakan angka yang dapat dihitung dan diukur. Analisis kuantitatif ini dimaksudkan untuk memperkirakan besarnya pengaruh secara kuantitatif dari perubahan satu atau beberapa kejadian lain menggunakan analisis statistik. Pengolahan data dengan menggunakan analisis kuantitatif melalui beberapa tahap, yaitu sebagai berikut :

1. Untuk mengukur variabel $(X)$ yaitu modal kerja digunakan rumus :

$$
\text { Rasio modal kerja }=\frac{\text { Aktiva lancar }}{\text { Total aktiva }} \times 100 \%
$$

2. Untuk mengukur variabel $(Y)$ yaitu profitabilitas digunakan rumus :

$$
\text { Marjin Laba Operasi }=\frac{\text { Laba bersih }}{\text { Penjualan }} \times 100 \%
$$

(Husnan \& Pudjiastuti, 2006)

3. Untuk menganalisis besarnya pengaruh antara modal kerja (variabel $X$ ) terhadap Profitabilitas (variabel Y), langkah-langkanya sebagai berikut:

1) Uji Koefisien Korelasi Sederhana

Analisis koefisien kolerasi digunakan analisis koefisien kolerasi produk momen. Di dalam analisis ini yang dicari adalah koefisien kolerasi yaitu angka yang menyatakan derajat hubungan antar variabel independen dengan variabel dependen atau untuk mengetahui seberapa kuat atau lemahnya hubungan antar variabel independen dengan dependen.

2) Analisis Koefisien Determinasi

Analisis koefisien determinasi $(\mathrm{Kd})$ bertujuan untuk menghitung besarnya presentase pengaruh variabel independen dengan variabel dependen.

3) Uji Signifikansi dengan Uji t

Analisis Uji t digunakan untuk menguji signifikansi (keberartian) pengaruh cost of production terhadap volume penjualan.

4) Uji Regresi Linier Sederhana

Analisis Uji Regresi Linier Sederhana digunakan untuk menguji pengaruh perubahan variabel independen yaitu cost of production terhadap perubahan varibel dependen yaitu volume penjualan.

5) Uji Signifikansi dengan Uji F

Analisis Uji $\mathrm{F}$ digunakan untuk menguji signifikansi (keberartian) pengaruh variabel independen yaitu cost of production terhadap variabel dependen yaitu volume penjualan hasil dari uji regresi linier sederhana.

Penelitian ini dilaksanakan di Perusahaan PT Bukit Asam (Persero) Tbk.

\section{HASIL DAN PEMBAHASAN}

Besarnya modal kerja pada PT Bukit Asam Tbk dari tahun 2015: 
Tabel 3. Rasio Modal Kerja PT Bukit Asam Tbk Tahun 2015-2019 (dalam jutaan)

\begin{tabular}{crrrrr}
\hline Tahun & Harta Lancar & Hutang Lancar & Total Aktiva & $\begin{array}{r}\text { Rasio Modal Kerja } \\
(\%)\end{array}$ & Perkembangan (\%) \\
\hline 2015 & Rp7.598.476 & Rp4.922.733 & Rp16.894.043 & $15,84 \%$ & - \\
2016 & Rp8.349.927 & Rp5.042.747 & Rp18.576.774 & $17,80 \%$ & $1,96 \%$ \\
2017 & Rp11.117.745 & Rp4.396.619 & Rp21.987.482 & $30,57 \%$ & $12,77 \%$ \\
2018 & Rp11.426.678 & Rp4.935.696 & Rp24.172.933 & $26,85 \%$ & $-3,72 \%$ \\
2019 & Rp11.679.884 & Rp4.691.251 & Rp26.098.052 & $26,78 \%$ & $-0,70 \%$ \\
Jumlah & Rp50.172.710 & Rp23.989.046 & Rp107.729.284 & $117,84 \%$ & $10,31 \%$ \\
Rata-Rata & Rp10.034.542 & Rp4.797.809,20 & Rp21.545.856,80 & $23,57 \%$ & $2,58 \%$ \\
\hline
\end{tabular}

Sumber : PT Bukit Asam Tbk

Tabel 4.1 menggambarkan modal kerja PT Bukit Asam Tbk selama lima tahun mulai tahun 2015 sampai dengan tahun 2019. Rasio modal kerja pada tahun 2015 sebesar $15,84 \%$. Pada tahun 2016 rasio modal kerja naik sebesar 1,96\%; dari 15,84\% tahun 2015 menjadi 17,80\%. Pada tahun 2017 rasio modal kerja naik sebesar 12,77\%; dari17,80\% tahun 2016 menjadi 30,57\%. Pada tahun 2018 penurunan sebesar 3,72\%; dari 30,57\% tahun 2017 menjadi $26,85 \%$. Pada tahun 2019 kembali mengalami penurunan sebesar 0,70\%; dari 26,85\% tahun 2018 menjadi $26,78 \%$.

Dari hasil analisis di atas dapat disimpulkan bahwa modal kerja yang diukur dengan rasio modal kerja pada PT Bukit Asam Tbk dari tahun ketahun mengalami fluktuatif dengan rata-rata setiap tahunnya sebesar $23,57 \%$, dan jika dilihat dari perkembangannya mengalami kenaikan sebesar $2,58 \%$ setiap tahunnya.

Berdasarkan perhitungan profitabilitas perusahaan PT Bukit Asam Tbk dapat disajikan dalam tabel sebai berikut:

Tabel 4. Profitabilitas PT Bukit Asam Tbk (dalam jutaan Rupiah)

\begin{tabular}{crrrr}
\hline Tahun & Laba Bersih & \multicolumn{1}{c}{ Penjualan } & Profitabilitas (\%) & Perkembangan (\%) \\
\hline 2015 & 2.037 .111 & 13.845 .199 & $14,71 \%$ & - \\
2016 & 2.024 .405 & 14.058 .869 & $14,40 \%$ & $-0,31 \%$ \\
2017 & 4.547 .232 & 1.947 .103 & $23,35 \%$ & $8,95 \%$ \\
2018 & 5.121 .112 & 21.166 .993 & $24,19 \%$ & $0,84 \%$ \\
2019 & 4.040 .394 & 21.785 .564 & $18,54 \%$ & $-5,65 \%$ \\
Jumlah & 17.770 .254 & 72.803 .728 & $95,19 \%$ & $3,83 \%$ \\
Rata-rata & $3.554 .050,8$ & $14.560 .745,6$ & $19,04 \%$ & $0,96 \%$ \\
\hline
\end{tabular}

Sumber : PT Bukit Asam Tbk

Tabel 4.2 menggambarkan tingkat profitabilitas PT Bukit Asam Tbk selama lima tahun mulai tahun 2015 sampai dengan tahun 2019. Profitabilitas pada tahun 2015 sebesar 14,71\%. Pada tahun 2016 penurunan sebesar 0,31\%; dari 14,71\% tahun 2015 menjadi $14,40 \%$. Pada tahun 2017 naik sebesar sebesar 8,95\%; dari 14,40\% tahun 2016 menjadi 23,35\%. Pada tahun 2018 naik sebesar 0,84\%; dari 23,35\% tahun 2017 menjadi 24,19\%. Pada tahun 2019 penurunan sebesar 5,65\%; dari 24,19\% tahun 2018 menjadi 18,54\%.

Dari hasil analisis di atas dapat disimpulkan bahwa profitabilitas pada PT Bukit Asam Tbk dari tahun ketahun mengalami fluktuatif dengan rata-rata setiap tahunnya sebesar $19,04 \%$ dan jika dilihat dari perkembangannya mengalami kenaikan sebesar 0,96\% setiap tahunnya.

Hasil Uji Koefisien Korelasi Sederhana

Hasil perhitungan, modal kerja yang diukur dengan rasio modal kerja dengan profitabilitas diperoleh nilai $r$ adalah sebesar 0,89 yang menunjukan tingkat keeratan hubungan yang sangat tinggi. Nilai $r$ juga positif, ini artinya modal kerja yang diukur dengan rasio modal kerja memiliki 
hubungan yang positif dengan profitabilitas perusahaan, ini berarti Jika modal kerja yang diukur dengan rasio modal kerja naik maka profitabilitas perusahaan akan meningkat.

Hasil perhitungan koefisien determinasi (KD) diperoleh hasil sebesar $79,21 \%$ artinya modal kerja yang diukur dengan rasio modal kerja berpengaruh sebesar $79,21 \%$ terhadap profitabilitas perusahaan dan sisanya $20,79 \%$ dipengaruhi oleh faktor lain yang tidak diteliti.

Hasil perhitungan uji $t$ diperoleh nilai thitung sebesar 3,3811.Dengan derajat kebebasan $(\mathrm{dk})=$ 3 dan $\alpha=0,05$ diperoleh nilai $t_{\text {tabel }}$ sebesar 3,182. Ini berartithitung $>t_{\text {tabel }}(3,3811>3,182)$. Makakesimpulannyamodal kerja yang dikukur dengan rasio modal kerja berpengaruh positif dan signifikan terhadap profitabilitas perusahaan pada PT Bukit Asam Tbk.

Hasil uji regresi linier sederhana diperleh persamaan regresi yaitu: $Y=3,76+0,65 X$, maka berdasarkan persamaan tersebut dapat dijelaskan Konstanta sebesar 3,76 artinya jika modal kerja yang diukur dengan rasio modal kerja $(X)$ nilainya 0 , maka profitabilitas perusahaan $(Y)$ nilainya positif sebesar 3,76. Koefisien regresi modal kerja yang diukur dengan rasio modal kerja $(X)$ sebesar 0,65 artinya jika modal kerja yang diukur dengan rasio modal kerja $(X)$ naik $1 \%$ maka profitabilitas perusahaan akan naik sebesar $0,65 \%$. Koefisien bernilai positif antara modal kerja yang diukur dengan rasio modal kerja terhadap profitabilitas perusahaan mengandung arti bahwa jika modal kerja yang diukur dengan rasio modal kerja naik maka profitabilitas perusahaan akan meningkat.

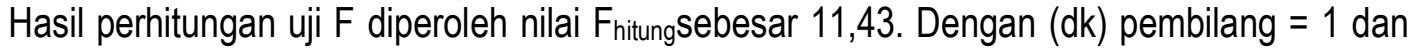
(dk) penyebut $=3$. dan $\alpha=0,05$ diperoleh nilai $F_{\text {tabel }}$ sebesar 10,13 . Ini berartiF $F_{\text {hitung }}>F_{\text {tabel }}(11,43>$ 10,13). Maka kesimpulannyamodal kerja yang diukur dengan rasio modal kerja berpengaruh positif dan signifikan terhadap profitabilitas perusahaan pada PT Bukit Asam Tbk.

Temuan dari hasil penelitian ini adalah bahwa Modal kerja yang diukur dengan rasio modal kerja mempunyai pengaruh positif dan signifikan terhadap profitabilitas perusahaan pada PT Bukit Asam Tbk, adapun besarnya pengaruh sebesar $79,21 \%$. Hasil penelitian ini sesuai dengan teori yang dikemukakan olehSubardi (dalam Yosi Andra Yani, Lidya Martha 2016:5) yaitu bahwa keputusan yang mendasari manajemen modal kerja yang sehat ada dua yaitu: "(1) Tingkat investasi optimal dalam aktiva lancar; dan (2) Campuran pembelanjaan jangka pendek dan pembelanjaan jangka panjang yang digunakan untuk mendukung investasi dalam aktiva lancar.Keputusankeputusan tersebut dipengaruhi oleh hasil yang diharapkan dari profitabilitas."

Disamping itu juga, hasil penelitian ini sesuai dengan hasil penelitian dari Tnius (2018), hasil penelitiannya adalah modal kerja berpengaruh signifikan terhadap profitabilitas pada PT Hanjaya Mandala Sampoerna Tbk, dan juga hasil penelitian yang dilakukan oleh Marda (2019),yang menyimpulkan bahwa modal kerja berpengaruh positif dan signifikan terhadap profitabilitas Pt Astra International Tbk di Bursa Efek Indonesia. Tetapi hasil penelitian ini tidak sesuai dengan hasil penelitian dari Reimeinda, Murni \& Saerang (2016), yang menyimpulkan hasil penelitiannya adalah Perputaran modal kerja bersih (Working Capital Turnover) tidak mempengaruhi Profitabilitas pada perusahaan telekomunikasi di Indonesia baik secara parsial maupun simultan. Begitu juga hasil penelitian dari Khorrunisa, Sasongko \& Endah (2017), yang menyimpulkan bahwa Secara simultan atau bersama-sama variabel modal kerja, cash turnover, receivable turnover dan inventory turnover berpengaruh tidak signifikan terhadap profitabilitas Pada PT.Mayora Indah Tbk.

\section{KESIMPULAN}

Berdasarkan hasil penelitian dapat kesimpulan sebagai berikut :

1. Besarnya modal kerja yang diukur dengan rasio modal kerja pada PT Bukit Asam Tbk dari tahun ketahun mengalami fluktuatif dengan rata-rata setiap tahunnya sebesar $23,57 \%$, dan jika dilihat dari perkembangannya mengalami kenaikan sebesar $2,58 \%$ setiap tahunnya. 
2. Besarnya tingkat profitabilitas pada PT Bukit Asam Tbk dari tahun ketahun mengalmi fluktuatif dengan rata-rata setiap tahunnya sebesar $19,04 \%$ dan jika dilihat dari perkembangannya mengalami kenaikan sebesar $0,96 \%$ setiap tahunnya.

3. Modal kerja yang diukur dengan rasio modal kerja mempunyai pengaruh positif dan signifikan terhadap profitabilitas perusahaan pada PT Bukit Asam Tbk, adapun besarnya pengaruh sebesar $79,21 \%$.

\section{REKOMENDASI}

Berdasarkan kesimpulan diatas, penulis memberikan saran atau rekomendasi berkaitan dengan masalah penelitian yaitu sebagai berikut:

1. Menstabilkan modal kerja PT Bukit Asam Tbk dengan mengontrol komponen-komponen yang mempengaruhi modal kerja sehingga dapat beroperasi secara ekonomis dan efisien.

2. Meningkatkan profitabilitas perusahaan dengan meningkatkan pengendalian terhadap elemenelemen modal kerja sehingga biaya yang dikeluarkan dapat terinci dengan baik.

3. Bagi peneliti selanjutnya diharapkan dapat melakukan penelitian yang sifatnya pengembangan dari penelitian ini terutama yang menyangkut modal kerja dan profitabilitas.

\section{UCAPAN TERIMAKASIH}

Puji syukur kepada Alloh SWT atas rahmat dan karunia-Nya sehingga dapat menyelesaikan penelitian yang berjudul "Pengaruh Modal Kerja Terhadap Profitabilitas Perusahaan Pada PT Bukit Asam Tbk."

\section{DAFTAR PUSTAKA}

Anwar, M. (2018). Dasar-Dasar Manajemen Keuangan. Jakarta: Prenada Media Group

Hanafi, M. M. (2018). Analisis Laporan Keuangan. Yogyakarta: Liberti

Husnan, S., \& Pudjiastuti, E. (2006). Dasar-Dasar Manajemen Keuangan.Yogyakarta: UPP STIM YKKPN.

Khorrunisa, R., Sasongko, H., \& Endah, R. M. (2017). Pengaruh Modal Kerja Terhadap Profitabilitas Pada Pt Mayora Indah,Tbk Periode 2006-2015. Jurnal Online Mahasiswa (JOM) Bidang Akuntansi, 4(1).

Munawir, S. (2019). Analisa Laporan Keuangan. Yoryakarta: Liberti

Riyanto, B. (2010). Dasar-dasar Pembelanjaan Perusahaan. Yogyakarta: UGM

Tnius, N. (2018). Pengaruh Modal Kerja Terhadap Profitabilitas Pada PT. Hanjaya Mandala Sampoerna Tbk.Jurnal Sekuritas.(Volume I; 71)

Wahyu, F. S. (2021). Pemanfaatan instagram sebagai media alternatif IPA dalam masa pembelajaran jarak jauh (pjj). J-KIP (Jurnal Keguruan dan IImu Pendidikan), 2 (2), 81-90.

Yani, Y. A., \& Martha, L. (2016). Pengaruh Modal Kerja Terhadap Profitabilitas Pada Perusahaan Kosmetik yang Terdaftar di Bursa Efek Indonesia. Jurnal Akuntansi. (Volume II; 5). 